\title{
Is Alzheimer's disease a Type of diabetes?
}

\author{
Alyne Mendonça Marques Ton* \\ Laboratory of Translational Physiology and Pharmacology, Vila Velha University, Brazil.
}

Submission: December 13, 2018; Published: January 11, 2018

*Corresponding author: Alyne Mendonça Marques Ton, Laboratory of Translational Physiology and Pharmacology, Pharmaceutical Sciences Graduate Program, Vila Velha University, Brazil.

\section{Opinion}

Alzheimer's disease (AD) is a progressive neurodegenerative disease characterized by loss of memory and impairment of multiple cognitive functions, to the detriment of hippocampal and cortical neurons. It is reported that neuronal loss may contribute to a $20-30 \%$ decrease in brain weight loss in patients with AD. This impairment in the counting and functionality of neurons occurs as a consequence of the accumulation of $\beta$-amyloid protein $(\beta-A)$ and neurofibrillary tangles. B-A protein is found in neuritic plaques of the brain with $\mathrm{AD}$ and is generated by abnormal processing of amyloid precursor protein (APP) in neurons. The process of generation of APP occurs through two pathways: the amyloidogenic pathway, in which APP undergoes a sequential proteolysis through the $\beta$ and $\gamma$ secretases enzymes, originating the $\beta$-A protein; and the non-amyloidogenic pathway, in which cleavage occurs through the $\alpha$-secretase enzyme within the $\beta$-A domain, generating soluble and non-amyloidogenic fragments that are cleaved by the enzyme $\gamma$-secretase.

The cause of abnormal APP processing and subsequent accumulation of $\beta$-A protein is unknown. However, factors such as genetics, age, lifestyle, diet, metabolic diseases and other pathologies such as Down syndrome are considered to be at risk for the onset of the disease. The $\beta$-A protein is generated in neurons, where APP and $\beta$ and secrete enzymes are present in many intracellular sites, such as the Golgi complex, endoplasmic reticulum, endosome-lysosome system and multivesicular bodies. Studies have shown that $\beta$-A protein represents the central cause of the development and progression of $\mathrm{AD}$, since it causes a series of events such as oxidative stress, synaptic loss and deterioration, inhibition of synaptic plasticity and hyperphosphorylation of Tau protein reported as one of the main biomarkers of the disease, together with the $\beta-A 2$ protein [1-3].

In the central nervous system (CNS), IGF / insulin signaling plays a critical role in the regulation and maintenance of cognitive function. Insulin, insulin-like growth factors 1 and 2 (IGF-1 and IGF-2) and receptor genes are expressed in glia cells and neurons throughout the brain, with the highest levels of expression being found in structures that are usually targets of degenerative diseases [4]. The IGF / insulin signaling axis exerts several functions, such as growth, survival, differentiation, migration, energetic metabolism, gene expression, protein synthesis, cytoskeletal assembly, synapse, neurotransmitter function and neuronal plasticity [4].

There has been a growing number of studies that support the concept that AD essentially represents a metabolic disease with impairment in energy production and utilization of glucose by the brain [5]. The metabolic abnormalities present in the disease in question are related to insulin resistance and insulin-like growth factor (IGF), and thus to the breakdown of signaling pathways that regulate the survival of neurons, energy production, gene expression and plasticity. It is reported that brain inhibition of IGF / insulin may increase APP expression, $\beta$-A protein accumulation, enzyme activity responsible for phosphorylation of Tau protein and generation of reactive oxygen and nitrogen species that cause protein damage, DNA, RNA and lipids; in addition, it promotes mitochondrial dysfunction and activates pro-inflammatory and pro-apoptotic cascades [4]. Furthermore, IGF / insulin resistance in the brain promotes a decrease in the expression of key genes required for homeostasis cholinergic, compromising systems that mediate neuronal plasticity, memory and cognition [6].

It is shown that the early stages of AD are characterized by cerebral deficit in the use of glucose, and the physiological and metabolic abnormalities related to energetic impairment worsen with the progression of the disease. The expression of genes related to IGF / insulin synthesis that mediates cholinergic / cognitive and metabolic functions is suppressed in AD [6]. In patients with $\mathrm{AD}$, deficiency in insulin signaling is due to the combined effect of their deficiency and brain resistance. These events are manifested by reduced responsiveness to the stimulation and functionality of their receptor, whereas IGF deficiency is associated with reduced gene expression and insulin levels in cerebrospinal fluid and brain. Thus, AD is considered a form of cerebral diabetes mellitus characterized by deficiency and insulin resistance, being called diabetes mellitus type 3 [4]. In addition, it is shown that the molecular, biochemical and signal transduction abnormalities present in $\mathrm{AD}$ are identical to those that occur in the presence of type 1 and type 2 diabetes mellitus $2[4,6]$. It is reported that the toxicity of $\beta$-A protein promotes insulin resistance in brain with concomitant oxidative stress and neuroinflammation $[7,8]$. 
In addition, insulin stimulation accelerates the mobilization of the Golgi complex $\beta$-A protein, where it is generated, to the plasma membrane, which causes greater stimulation of insulin secretion [4]. In addition, it is reported that insulin signaling in the brain may prevent both processing of APP and clearance of $\beta$-A protein. The accumulation of $\beta$-A protein exacerbates this picture, since $\beta$-A protein causes disruption of insulin signaling by competition or reduction of insulin affinity with its receptor [2,4]. Studies have shown that individuals who present with glucose intolerance, insulin secretion deficiency or type 2 diabetes mellitus have a significantly higher risk of developing $\mathrm{AD}$, since peripheral insulin resistance is a triggering factor for their resistance cerebral $[9,10]$. These events promote neuroinflammation and increase APP expression. Through the action of the $\beta$ and $\gamma$ secretases enzymes, the protein in question is cleaved, and the exaggerated generation of neurotoxic peptides and oligomers that promote increased oxidative stress and GSK-3 $\beta$ activation: glycogen synthase kinase3ß; CDK5: cyclin-dependent kinase-5; P38 MAPK: mitogenactivated protein kinase P38; JNK: N-terminal c-Jun kinase; PP2A: protein phosphatase 2; EROS: reactive oxygen species $[11,12]$. It is reported that individuals with impaired glucose tolerance, insulin secretion, type 2 diabetes mellitus, dyslipidemic diseases or obesity present a significant increase in the risk of developing mild cognitive impairment or dementia $[13,14]$. Thus, it is suggested that therapeutic strategies designated for treatment of type 2 diabetes mellitus, obesity and insulin resistance may be useful in slowing the progression or reducing the severity of AD.

\section{References}

1. Bomfim TR, Forny Germano L, Sathler LB, Brito Moreira J, Houzel JC et al. (2012) An anti-diabetes agent protects the mouse brain from defective insulin signaling caused by Alzheimer's disease-associated A $\beta$ oligomers. J Clin Invest 122(4): 1339-1353.

2. Tapiola T, Alafuzoff I, Herukka SK, Parkkinen L, Hartikainen P, et al. (2009) Cerebrospinal fluid \{beta\}-amyloid 42 and tau proteins as biomarkers of Alzheimer-type pathologic changes in the brain. Arch Neurol 66(3): 382-389.
3. Hernández F, de Barreda EG, Fuster Matanzo A, et al. GSK3: A possible link between beta amyloid peptide and tau protein. Exp Neurol 223(2): 322-325.

4. de la Monte SM (2012) Brain Insulin Resistance and Deficiency as Therapeutic Targets in Alzheimer's Disease. Curr Alzheim Res 9(1): 35-66.

5. Accardi G, Caruso C, Colonna Romano G, Camarda C, Monastero R, et al. (2012) Can Alzheimer disease be a form of type 3 diabetes? Rejuvenation Res 15(2): 217-221.

6. Talbot K, Wang H, Kazi H, Han LY, Bakshi KP, et al. (2012) Demonstrated brain insulin resistance in Alzheimer's disease patients is associated with IGF-1 resistance, IRS-1 dysregulation, and cognitive decline. J Clin Invest 122(4): 1316-1338.

7. Furst AJ, Lal RA, (2011) Amyloid- $\beta$ and glucose metabolism in Alzheimer's disease. J Alzheimer's Dis 26(3): 105-116.

8. Jovanovic Z (2012) Mechanisms of neurodegeneration in Alzheimer's disease. Med Pregl 65(7-8): 301-307.

9. Musen G, Jacobson AM, Bolo NR, Simonson DC, Shenton ME, et al. (2012) Resting-state brain functional connectivity in altered in type 2 diabetes. Diabetes 61(9): 2375-2379.

10. Priyadarshini M, Kamal MA, Greig NH, Reale M, Abuzenadah AM, et al. (2012) Alzheimer's disease and type 2 diabetes: exploring the association to obesity and tyrosine hydroxylase. CNS Neurol Disord Drug Targets 11(4): 482-489.

11. Pimenta FS, Ton AMM, Guerra TO, Alves GG, Campagnaro BP (2018) Unmasking the gut-brain axis: How the microbiota influences brain and behavior. J Food Microbiol 2(S1):23-34.

12. Ton AMM, Arpini CM, Campagnaro BP, Thiago Melo C Pereira, Elisardo C Vasquez (2018) Alzheimer's disease: A brief update on the influence of gut microbiota and the impact of functional food. J Food Microbiol 2(1): 11-15.

13. Umegaki H (2012) Neurodegeneration in diabetes mellitus. Adv Exp Med Biol 724: 258-265.

14. Lee EB (2012) Obesity, leptin, and Alzheimer's disease. Ann N Y Acad Sci 1243: 15-29.

\section{Your next submission with Juniper Publishers} will reach you the below assets

- Quality Editorial service

- Swift Peer Review

- Reprints availability

- E-prints Service

- Manuscript Podcast for convenient understanding

- Global attainment for your research

- Manuscript accessibility in different formats

( Pdf, E-pub, Full Text, Audio)

- Unceasing customer service

Track the below URL for one-step submission

https://juniperpublishers.com/online-submission.php 